affected the quality of the systems we moderns depend on? Have aeroplanes, telephone networks, power plants, department-store bills and the like become more reliable or less with the spread of microchips? Answers to such questions lie beyond the scope of this book.

Instead, Wiener examines each advance for potential threats. With repetition, this litany wears thinner as it proceeds. Publishing books electronically will lead to multiple rewrites of the classics. "How are we going to tell which is the original?" the author asks, thereby rekindling a debate that must have accompanied the advent of movable type.
Although the author may possess a mild case of technological paranoia, she seems to have come by that condition honestly, through association with improvementminded workers in the field. Given our society's pervasive, and growing, dependence on software, the computer industry and its customers can ill afford complacency. In that spirit, the continuing selfcriticism which this book depends on for much of its substance provides a healthy stimulus for continuing improvements.

Arno A. Penzias is vice president of research at AT\&T Bell Laboratory, PO Box 636, 600 Mountain Avenue, Murray Hill, New Jersey 07974-0636, USA.

\title{
A defender of science
}

\section{A. Rupert Hall}

Defining Science: William Whewell, Natural Knowledge and Public Debate in Early Victorian Britain. By Richard R. Yeo. Cambridge University Press: 1993. Pp. 272. £35, \$54.95.

William Whewell (1794-1866), the pivot of this study, a close contemporary of Babbage, Herschel and Peacock, was a greater pundit than any of these. Ascending the successive steps of classicist, mathematician, priest and professor of moral sciences, he at last attained one of the finest offices in the British prime minister's gift, the mastership of Trinity College, Cambridge: a reward not often given to a Fellow who has made his way up the college ladder. Yet, as Whewell recognized regretfully, no theorem or discovery bears his name. His early textbooks of mechanics were good, he contributed to the modernization of Cambridge mathematics and mineralogy, he stimulated and advanced global knowledge of the tides; but even these relatively modest accomplishments were completed before he was much over 40 . The rest of his work and the bulk of his fame lay outside scientific teaching and innovation.

If this was Whewell's science - which is not of prime concern to Yeo - what was his "omniscience", his "foible" according to Sydney Smith? As for so many Victorians, Germany was an intellectual inspiration: Whewell published a book on Gothic German architecture, trans-

\section{4 review supplements} Nature's review supplements next year are Spring Books (24 March), Autumn Books (17 November) and New Journals (29September). The latter will cover journals launched during or after June 1992 with four separate numbers issued by the end of April 1994 lated German poetry, and himself wrote English hexameters; he read the German moralists - not, perhaps, the German theologians who so impressed the young George Eliot. He preached influential sermons, he wrote books on morality, he contributed to the mid-Victorian educational debate (ever advising that the Cambridge disciplines of Greek and geometry were the essential foundations of learning), he deplored the Oxford Tractarians and defended the divine creation. Above all, Whewell wrote universally about science - Yeo would amend Sydney Smith's quip to make "metascience" Whewell's foible. Some of this bulky writing was addressed to readers of the reviews perhaps one would today hardly imagine Sir Michael Atiyah composing an essay equivalent to The General Bearing of the Great Exhibition on the Progress of Art and Science (1851) - much was at the highest level of philosophical debate, notably in his Philosophy of the Inductive Sciences (1840). His dissensions from Locke, Comte, J. S. Mill and other giants remain to this day of lively technical interest. Nevertheless, one sees what a vast intellectual gulf divides Whewell from such a man of the next generation as James Clerk Maxwell, not to mention Charles Darwin, 15 years his junior and a practitioner of sciences still regarded by Whewell as speculative.

What did Whewell hope for from his "metascientific" studies, publications of deep thought and intense effort? He was far from alone in embarking on a 'public debate' about 'natural knowledge in early Victorian Britain' (to rearrange Yeo's subtitle): Babbage, Herschel, Brewster, Sedgwick, Murchison and many others aired their views on what science is (or is not), what its boundaries and prospects are, why it is necessary to mankind and why it should be promoted (or discouraged). Like many contemporaries,
Whewell held the most advanced and mathematical departments of science, such as astronomy and mechanics, to be essentially perfect and infallible; one problem therefore was the relationship of contemporary non-mathematical sciences, and mathematical science before Newton, to these perfected bodies of knowledge. Whewell discussed the first of these aspects of the problem in his Philosophy of the Inductive Sciences, the second aspect in his earlier History of the Inductive Sciences (1837). These two closely connected books are the twin props of his reputation today.

Whewell was a massive and authoritative figure. Perhaps his philosophical weight was most effectively cast against a facile Baconianism or positivism, and he may have agreed with a friend that 'Plato is worth 10,000 Aristotles and 100,000 Lockes', for Locke's philosophy treated the human mind as if it were "the same sort of thing as Babbage's Calculating Machine" - a surprising comparison for 1822. It was a philosophy (Whewell thought) hostile to both science and religion.

Yeo writes of Whewell as a defender of science, though he never clearly defines the opposition. Whewell was never so hot a critic of governmental apathy and the Royal Society as was Babbage, nor did he believe that universities should be seats of research. He argued that utilitarianism misrepresented science, without alleging that this philosophy obstructed it. Classicists might maintain the superiority of their studies for human life, but with them Whewell had no dispute. High churchmen (like popes) distrusted science; Whewell (like Newton) insisted on the reconciliation of religion and science. Essentially his ideas were conservative (arousing Huxley's criticism) as may be seen in his rejection of Lyell's geology (in the concluding pages of his History) and the whole final chapter of On the Philosophy of Discovery (1856).

A more consistent concentration on Whewell's (qualified) role as an advocate of scientific knowledge, and of the importance of the endeavour to understand nature within European thought, might have brought a sharper focus to this rather diffuse study, which still leaves Whewell's stature enigmatic. The importance of the great reviews in British intellectual life in his time is well brought out; the History is well assessed; the treatment of Whewell's philosophy is heavy going. Fashionable use of such words as 'space', 'visibility', 'agenda', 'rhetoric' and 'discourse' in a figurative sense does not make for clarity. A book entitled Defining Science might reasonably have ended with a statement of Whewell's definition.

A. Rupert Hall is at 14 Ball Lane, Tackley, Oxfordshire OX5 3AG, UK. 